\title{
Анна Клепикова
}

Claire L. Shaw. Deaf in the USSR: Marginality, Community, and Soviet Identity, 1917-1991. Ithaca, NY: Cornell University Press, 2017. 292 pp. ISBN 978-15017-1366-8.

Анна Клепикова, Европейский университет в Санкт-Петербурге. Адрес для переписки: Гагаринская ул., 6/1, литера А, Санкт-Петербург, 191187, Россия. aklepikova@eu.spb.ru.

В нашем российском обществе привычно думать о глухих и людях с нарушениями слуха в терминах инвалидности, глухота интерпретируется как медицинская проблема. Такой взгляд представляется, с одной стороны, наследием советского отношения к людям с теми или иными «недостатками», а с другой стороны, находится в русле тенденции отношения к людям с нарушениями слуха в европейской культуре в целом.

Одной из характерных «рамок» для интерпретации глухоты в Европе и США в XX веке стали представления из области евгенической теории, которые в нацистской Германии привели к уничтожению тысяч людей с нарушениями слуха и другими физическими и ментальными особенностями (Mostert 2002; Noack and Fangerau 2007) ${ }^{1}$. В США принимали специальные меры для того, чтобы глухие люди не могли вступить в брак и произвести на свет потомство, а ныне американские граждане с нарушениями слуха позиционируют себя как носителей особой культуры и языковое меньшинство, но не как инвалидов. Впрочем, и в более ранней истории европейской культуры можно найти примеры недискриминирующего отношения к людям с нарушениями слуха: так, на острове Мартас-Винъярд (штат Массачусетс, (ША) в XVII - начале XX веках в результате того, что у сравнительно большой группы людей наблюдалась наследственная глухота, сложилась такое сообщество, в котором слышащие пользовались жестовым языком наравне с глухими (Groce 1985; Lane 2002; Kudlick 2003).

Книга Клэр Шоу, вышедшая в 2017 году в издательстве Корнеллского университета, «Deaf in the USSR: Marginality, Community, and Soviet Identity, 1917-1991» рассказывает о различных социальных процессах вокруг глухих людей на протяжении всей истории СССР и демонстрирует, что, вопреки интуитивным представлениям, на протяжении советского периода глухие воспринимались не только в рамках так называемой медицинской, патологизирующей, модели инвалидности. Скорее, такой взгляд нередко соседствовал и конфликтовал с представлениями о глухоте как о социальной проблеме.

Во многом, как пишет Шоу, советский взгляд на глухих был более прогрессивным, чем западный. Поскольку социалистическая идеология подразумевала расширение возможностей для различных меньшинств, то, в отличие от западных

1 Также см. книгу о глухих людях в нацистской Германии (Biesold 1999). 
стран, где процветал евгенический подход к глухим, в СССР в 1920-1930-е годы люди с нарушением слуха были уравнены в правах с остальными гражданами (до революции значительная часть глухих считалась неправоспособными, находясь под опекой). В каком-то смысле глухие в рамках нового советского государства попадали в разряд групп вроде коренных малочисленных народов - прежде всего из-за их языковой специфики. При этом Шоу показывает, что сами люди с нарушением слуха были вовсе не пассивны в деле формирования своей новой советской идентичности: активисты весьма охотно взяли на вооружение левую идеологию и успешно использовали ее для отстаивания своего статуса не-инвалидов.

Вообще книга Шоу сама по себе является ценной хотя бы потому, что это одна из немногих работ, посвященных истории инвалидности в СССР и на постсоветском пространстве. Среди ее немногочисленных предшественников можно выделить сборник работ под редакцией Уильма Маккага и Льюиса Сигельбаума (McCagg and Siegelbaum 1989), несколько статей в сборнике Майкла Рассела и Елены Ярской-Смирновой (Rassell and Iarskaia-Smirnova 2014) и книги Марии-Кристины Гальмарини-Кабала (Galmarini-Kabala 2016), исследования Сары Филлипс (Phillips 2009, 2010), и посвященные непосредственно театру глухих в СССР работы Анастасии Кайатос (например: Кайатос 2012).

Автор ссылается на все перечисленные труды, однако нельзя сказать, что книга написана в русле направления disability studies. Скорее, она вообще не прибегает ни к какой конкретной теории, лишь время от времени с разной степенью уместности ссылаясь на различные концепции историков и культурологов, писавших об СССР (таких как Шейла Фитцпатрик или Катриона Келли). Шоу интересуют пути создания и конструирования идентичности глухих в рамках советской политики идентичности - именно вокруг обсуждения идеи о неразрывной связи идентичности сообщества неслышащих людей и «советскости» построено введение да и вся книга в целом. То есть идентичность глухих и ее трансформации рассматриваются как частный случай реализации советской идентичности.

Главной же чертой советского трансформационного проекта и политики идентичности было создание человека рабочего. Поэтому включение глухих в трудовую производственную деятельность на заводах было гарантом включения их в круг «нормальных» советских граждан (так же, как по Фридриху Энгельсу труд сделал из обезьяны человека), и такие возможности для глухих, по крайней мере, для некоторых из них, были - в частности, на заводах для бригад глухих были предусмотрены сурдопереводчики. Работать - значило не быть инвалидом, и в случае человека рабочего глухота не играла первостепенной роли. Через преодоление своего недостатка и вызванной им «отсталости» глухие включались в труд и тем самым «нормализировались» и встраивались в ткань нового советского общества - и одновременно, вследствие своего недостатка и общественных представлений о нем, постоянно исключались. Путь глухих в советскую эпоху представлен Шоу как беспрестанный дрейф между включенностью, то есть «советскостью», и, напротив, маргинальностью, исключенностью из советского общества. Одно из достоинств книги заключается в том, что автор не пытается представить 
этот процесс более стройным и однонаправленным, чем он был в действительности, демонстрируя его во всей сложности, противоречивости и непредопределенности, ведь сам конструкт правильной «советскости» претерпевает постоянные изменения.

Книга написана на материалах архивных документов, публицистики и мемуаров, с привлечением анализа художественных произведений, и выстроена по хронологическому принципу; структурно и содержательно она частично повторяет ранее защищенную PhD-диссертацию автора (Shaw 2010) и, видимо, оттого несет на себе некоторый отпечаток ученичества. Так, каждая глава снабжена отчетливым заключением, в котором иногда повторяются вещи, уже сказанные ранее, что для монографии выглядит своего рода формальностью, несколько затрудняя чтение. Однако в качестве введения в начале каждой части Шоу разбирает какойлибо иллюстративный кейс - фильм, статью в газете, фотографию, - чем, несомненно, завлекает читателя.

В первой главе Шоу описывает основание в 1920-е годы по инициативе активистов Всероссийского общества глухих (ВОГ), в задачи которого должна была входить в частности помощь с трудоустройством глухих, культурная работа, профилактика нарушений слуха. При этом, с одной стороны, активисты противились попыткам государства обозначить их как инвалидов, настаивая на том, что они культурное меньшинство, но с другой стороны, обосновывая создание всероссийской организации, апеллировали к необходимости «защиты». Как становится понятно, такая дихотомия в риторике как активистов, так и государства будет характерна для всего советского периода.

В этой же главе становится очевидно, что в действительности книга будет посвящена не столько истории глухих в СССР (как это заявлено в названии), сколько идеологии и деятельности ВОГ. Значительная часть материалов, на которые опирается автор, так или иначе крутится вокруг глухих активистов В0Г и соответственно их понимания идентичности сообщества, которое безусловно гораздо шире и разнообразнее. Однако добраться до неактивистской точки зрения нелегко, изучая любое более или менее маргинальное сообщество, а исторические материалы, видимо, и вовсе не оставляют здесь альтернатив.

Во второй главе Шоу рассматривает последовательное развитие и расширение в 1930-е годы В0Г, куда постепенно вошли все локальные структуры, ассоциации и инициативы глухих. Государство же активно включило глухих в свою «телесную политику» и как рабочих на советских заводах, и как отдельную колонну марширующих на первомайской демонстрации с плакатом «Глухонемые». В то же время в 1930-е для полноценной «советскости» стало уже недостаточно быть просто рабочим: необходимо было разбираться в советской идеологии. Глухие же, точнее - «глухонемые», как их тогда было принято называть, по причине своего недостатка считались «отсталыми», и из практической проблемы глухота превратилась в идеологическую.

Необходимо было бороться с глухотой и «немотой» силами образования, используя как основной подход орализм, то есть методику обучения глухих людей устной речи, - в противовес мануализму, основывающемуся на использовании 
более органичной для глухих жестовой речи. При этом доступ к образованию оказывался неодинаков для разных категорий глухих: поздно оглохшие дети уже владели устной речью, люди же, оглохшие во взрослом возрасте, имели расширенные возможности трудоустройства. Шоу систематически указывает на неоднородность тех, кто попадал в категорию «глухонемых» или «глухих», и, соответственно, на различия в их самоидентификации, потребностях, а также в доступе к ресурсам.

В третьей главе Шоу рассказывает об изменениях в сообществе глухих и структуре ВОГ в годы после окончания Второй мировой войны. Парадоксально, но послевоенная ситуация во многом подтолкнула развитие ВОГ. Многие во время войны потеряли слух или получили другие инвалидизирующие травмы, и им, соответственно, было положено дальнейшее государственное обеспечение. Оглохшим ветеранам следовало предоставлять рабочие места или, как и другим инвалидам, платить пособия. Решение проблем военных ветеранов, вопросы их трудоустройства, обеспечения различными сервисами и льготами были возложены на ВОГ. Это позволило организации расширить свои функции, переориентировавшись на полное обслуживание нужд глухих людей; в то же время новый тип управленцев, возглавивших структуры ВОГ, позволил радикально улучшить ее финансовое положение.

Эти факторы среди прочего привели к расцвету ВОГ - именно «золотому веку» в истории организации и посвящена следующая, четвертая, глава книги. Как будто в противовес сталинским заявлениям в «Дискуссии по вопросам языкознания» 1950 года об аномальности людей, использующих жестовый язык, именно на 1950-1960-е годы пришелся его расцвет. Во времена хрущевской оттепели началось составление первого словаря жестового языка, проводились первые попытки его кодификации, процветал Московский театр мимики и жеста, массово открывались клубы, где языком общения и культурной и идеологической работы был жестовый. ВОГ же получило возможность не только открывать, но и строить новые учреждения для глухих (санатории, детские лагеря, спортивные клубы, интернаты, общежития), тем самым обеспечивая в том числе и трудоустройство глухих рабочих. В это время глухота оказывается легитимирована как специфический культурный опыт и, одновременно, происходит все большее обособление этой культуры от советского общества.

В пятой главе Шоу переходит к параллельно существовавшим представлениям о глухих как о людях, как раз недостаточно культурных и опасных. На материалах нескольких публикаций и дискуссий в прессе она описывает моральную панику вокруг глухих воров и бродяг и в особенности - глухих женщин с асоциальным поведением. Ответственность за ресоциализацию подобных отклоняющихся индивидов, портивших имидж сообщества, была также частично возложена на ВОГ.

В брежневскую эпоху, о которой речь идет в заключительной, шестой, главе, функции ВОГ во многом свелись к обслуживанию материальных потребностей глухих людей, в частности, к обеспечению их слуховыми аппаратами. Действительно, технологический и медицинский прогресс немало повлияли на распад «культуры 
глухих»: успехи в этой сфере позволили уменьшить число глухих детей, взрослые, терявшие слух, могли носить слуховой аппарат и продолжали пользоваться устной речью. Глухие стали видеться объектами научно-технического вмешательства: это люди, чью глухоту можно исправить, - что неизбежно означало их инвалидизированную позицию. Дискурс ВОГ впервые за всю историю стал однозначно склоняться к медицинской, а не социальной модели глухоты, глухота стала пониматься в терминах индивидуальной трагедии - именно как физический, а не «социальный» недостаток. Шоу описывает бюрократизацию ВОГ, формализм, коррупцию и постепенный распад организации в эпоху застоя. В то же время это был период эмоциональных размышлений неслышащих людей, утративших веру в «советскую идентичность», о природе своей трагедии и о смысле жизни.

В эпилоге широкими мазками дана картина жизни сообщества глухих в 1990е годы. В этот период неслышащие люди начали критично относиться к ВОГ и многие стали переходить в альтернативные институты, в частности, под опеку Русской православной церкви. С распадом СССР идеологические основы идентичности были утрачены, влияние западных представлений о deaf culture возросло, но сохранилось требование государственного социального обеспечения. В России 1990-х годов, как отмечает Шоу, в выборе своей идентичности сообщество глухих дрейфует между медицинским и социальным пониманием глухоты.

Еще во введении к книге Шоу отмечает, что в основе идентичности сообщества глухих лежит язык - жестовый язык, который является коммуникативным барьером для взаимодействия с миром слышащих и тем самым очерчивает границы сообщества. С одной стороны, обучение по методике орализма подразумевает расширенные возможности дальнейшего включения в мир слышащих. С другой стороны, отказ от жестового языка напрямую угрожает идентичности сообщества. Любопытно, что, отмечая ключевую роль языка для определения идентичности глухого человека, Шоу лишь поверхностно касается собственно языкового вопроса в книге. Глухие из деревень, приехавшие в города трудоустраиваться на заводы, были носителями в действительности не единого для всех жестового языка, но, по всей видимости, различных локальных вариантов так называемого home sign ${ }^{2}$. Шоу упоминает о необходимости унификации жестового языка в практических целях, о том, что глухие испытывали трудности в восприятии письменных инструкций, и о том, что на заводах был выработан и институализировался «городской жестовый язык». Однако она ничего не говорит об особенностях этих языков, о том, как происходила унификация и почему рабочие не понимали письменных инструкций.

Дело в том, что грамматика и синтаксис устной речи радикально отличаются от грамматики и синтаксиса жестового языка, носителем которого являются глухие люди и некоторые слышащие, выросшие в семьях с глухими родителями. Перевод привычной нам устной или письменной речи при помощи так называемой калькирующей жестовой речи тоже не достигает цели: «калька» остается не-

2 Этот термин употребляется в отношении некодифицированной системы жестов, вырабатываемой в семье или небольшом сообществе, где кто-то из его членов (ребенок или взрослый) не слышит. 
прозрачной для глухих носителей жестового языка ${ }^{3}$ Шоу ничего не говорит об использовании калькирующего метода - возможно, она отсылает к нему в четвертой главе, говоря о связи представлений о «культурности» с речью и идее о том, что устная речь должна обогатить и усовершенствовать бедный и недостаточно «культурный» жестовый язык глухих, но это не прояснено. То же самое касается и письменной речи: обычная письменная речь непонятна для глухих, поэтому неясно, что давало именно глухим (а не слабослышащим, например) субтитрирование фильмов в хрущевскую эпоху. Не говорит она и о разнице в вопросе выбора языка между глухими и слабослышащими, и о вероятном противостоянии этих в действительности двух разных сообществ.

Шоу не останавливается подробно на методиках обучения, а педагогические дебаты вокруг этих методик (типичные не только для нашей страны) обозревает довольно скупо, рассматривая детальнее лишь вопрос о том, в какой мере стоит поддерживать остаточный слух у детей. Она только вскользь упоминает о психологе Льве Выготском, различных дефектологических школах и разгроме педологии в 1936 году, особо не проясняя идеологических основ выбранных педагогических и методологических решений (стоит отметить, что в диссертации этому уделено больше места). Как сложилось, что к концу советского периода в школах для глухих стали преподавать слышащие учителя при помощи калькирующей жестовой речи с опорой на оральный метод, а жестовый язык глухих оказался маргинализирован? Как произошло, что сурдопереводчиков обучали только «кальке» и новости по телевизору с сурдопереводом оказывались непонятны глухим? Книга дает лишь намеки на некоторые объяснения, но не приближается к ответам на эти вопросы. А читатель, который не имеет представления об устройстве жестового языка и о том, что на практике стоит за наименованиями различных методик, может ничего и не понять.

Надо сказать, что некоторый недостаток книги заключается в том, что описываемые в ней факты оказываются почти полностью деконтекстуализированы. Так, лишь изредка приводится сравнительный материал из области американской или других культур и точно так же редко рассказывается о том, какие параллельные процессы в СССР происходили в отношении других групп людей с инвалидностью (например, слепых или людей с физическими нарушениями). Более того, работа касается исключительно России - материалы из других союзных республик не затрагиваются. Понятно, что невозможно охватить всего, но подобная контекстуализация позволила бы сделать обобщения иного порядка.

В то же время избегание натянутых обобщений при столь детальной историографии оказывается скорее достоинством: это позволяет спуститься на микроуровень, чтобы увидеть неоднозначность и неоднородность дискурсов и сложную механику социальных процессов вокруг сообщества глухих. Отмеченные же выше лакуны дают возможность ставить новые вопросы и вдохновляют на поиск ответов на них.

3 В частности, это показано в магистерских диссертациях, посвященных современному сообществу носителей русского жестового языка (Лебедева 2010; Кудряшева 2011). 


\section{СПИСОК ЛИТЕРАТУРЫ}

Кайатос, Анастасия. 2012. «Говорящие в беззвучии: скорее молчаливы, чем немы. Советский театр глухих и пантомима после Сталина». Журнал исследований социальной политики 10(2):213-234.

Кудряшева, Алина. 2011. «Социолингвистическая ситуация в российском сообществе глухих: варианты языка и типы носителей». Выпускная квалификационная работа. СПб.: НОУ ИДПО «Европейский университет в Санкт-Петербурге».

Лебедева, Валентина. 2010. ““Мир Глухих” в Петербурге: социальная организация сообщества». Выпускная квалификационная работа. СПб.: НИУ «Высшая школа экономики».

Biesold, Horst. 1999. Crying Hands: Eugenics and Deaf People in Nazi Germany. Washington, DC: Gallaudet University Press.

Galmarini-Kabala, Maria Cristina. 2016. The Right to Be Helped: Deviance, Entitlement, and the Soviet Moral Order. DeKalb: Northern Illinois Press.

Groce, Nora. 1985. Everyone Here Spoke Sign Language: Hereditary Deafness on Martha's Vineyard. Cambridge, MA: Harvard University Press.

Kudlick, Catherine. 2003. "Disability History: Why We Need Another 'Other.'” The American Historical Review 108(3):763-793.

Lane, Harlan. 2002. “Do Deaf People Have a Disability?" Sign Language Studies 2(4):356-379.

McCagg, William, and Lewis Siegelbaum, eds. 1989. The Disabled in the Soviet Union: Past and Present, Theory and Practice. Pittsburgh, PA: University of Pittsburgh Press.

Mostert, Mark. 2002. "Useless Eaters: Disability as Genocidal Marker in Nazi Germany." The Journal of Special Education 36(3):157-170.

Noack, Thorsten, and Heiner Fangerau. 2007. "Eugenics, Euthanasia, and Aftermath." International Journal of Mental Health 36(1):112-124. doi:10.2753/IMH0020-7411360111.

Phillips, Sarah. 2009. “'There Are No Invalids in the USSR!': A Missing Soviet Chapter in the New Disability History." Disability Studies Quarterly 29(3):1-35.

Phillips, Sarah. 2010. Disability and Mobile Citizenship in Postsocialist Ukraine. Bloomington: Indiana University Press.

Rassell, Michael, and Elena Iarskaia-Smirnova, eds. 2014. Disability in Eastern Europe and the Former Soviet Union: History, Policy and Everyday Life. Abingdon, UK: Routledge.

Shaw, Claire Louise. 2010. “Deaf in the USSR: 'Defect' and the New Soviet Person, 1917-1991." PhD dissertation, School of Slavonic and East European Studies, University College London. 